International Journal of Engineering \& Technology, $7(3.31)(2018) 240-248$
International Journal of Engineering \& Technology
WPC
Website www.sciencepubco.com/index.php/IJET
Research paper

\title{
Integration of Geology, Hydrogeology and Geomorphology for Groundwater Occurrence in A Hard Rock Region from Parts of Nalgonda District, Telangana State, India, Using Remote Sensing and G.I.S Techniques
}

\author{
K.M.Ganesh ${ }^{1 *}$,M. Jagannadha Rao $^{2}$ G. Jai Sankar ${ }^{3}$, V.K.S.K. Sai Vadapalli ${ }^{4}$ \\ ${ }^{1}$ Department of Civil Engineering, S.R.K.R. Engineering College, Bhimavaram, Andhra Pradesh, India-534204 \\ ${ }^{2}$ Department of Geology, College of Science and Technology, College of Engineering, Andhra University, Visakhapatnam, Andhra \\ Pradesh, India-534204 \\ ${ }^{3}$ Department of Geo-Engineering, College of Engineering, Andhra University, Visakhapatnam, Andhra Pradesh, India-534204 \\ ${ }^{4}$ Department of Information Technology, S.R.K.R. Engineering College, Bhimavaram, Andhra Pradesh, India-534204 \\ *Corresponding author E-mail:lakshmimanojna.k@gmail.com
}

\begin{abstract}
The study area is located in and around Nalgonda town in Nalgonda district, Telangana state. For the detailed investigation of the groundwater condition of a part of this district and covers an area of about 2880 sq.km. in Narkatpalli, Chityal, Katangur, Nakrekal_etc. mandals have been selected. Survey of India toposheets on 56 0/4, 0/8, P/1, P/5, Scale - 1: 50,000, IRS ID LISS III satellite imagery using remote sensing and G.I.S. techniques. A detailed study is carried out by classifying the wells into four categories. The groundwater regime with reference to depth water table fluctuation has been evaluated in the study area. The deeper wells mainly occur or observed to occur in the central and southeastern parts of the study area whereas the shallow wells are confined to northern, eastern and southeastern parts of the study area. Also the drainage pattern is observed as medium to coarse textured and dendritic to subdendritic type, which is characteristic of hard rock terrain and develops in regions of homogeneity. The field data provides the information about the depth to water table, and fluctuation of the groundwater. The best suitable areas identified were mainly in shallow valley fill is mostly composed of sandy material, which are generally good to excellent of groundwater prospects. Most of the area posed good groundwater recharge capacity. Based on these studies on lineament density map of the entire study area has been prepared indicating areas of high, moderate and low density lineaments. The important observation is that the deeper wells are having low fluctuation whereas the shallow wells are characterised by high fluctuation and high density lineaments. To study the hydrogeological conditions in the area, field investigations were carried out and 94 wells were inventoried. Groundwater occurs in the study area under water table and semi-confined conditions limited to weathered and fractured zones. The zone of weathering ranges from $0 \mathrm{~m}$ (near inselbergs) to $17 \mathrm{~m}$. The joints and fractures, which act as conduits for the movement of groundwater are responsible for the good yield of water from the wells.
\end{abstract}

Keywords: Hydrogeology; Geology; Groundwater; Remote sensing and G.I.S.

\section{Introduction}

Groundwater forms a very little quantity when compared to the total water available on the earth. It is vital for all living beings especially human beings. Groundwater is an important natural resource, especially in those parts of the country that don't have ample surface-water sources, such as the arid west of India.

All life directly and indirectly depends on water. So the evolution of life became possible on earth because of the presence of liquid water. The total amount of water available in the hydrosphere is 1386 M.C.M. Out of this, fresh water constitutes $2.5 \%$. The groundwater constitutes $29.9 \%$ of the fresh water, of which $0.9 \%$ exists in the form of soil moisture, swamp water, perma frost [1].

The day to day increase in demand, availability, and cost factors are playing a major role on the utilisation of the groundwater for water supply needs of townships and rural areas. The availability of good quality groundwater is more important than the quantity.
The study area falls under semi-arid tract and receives scanty rainfall and has limited groundwater resources. It has a limited number of minor irrigation tanks, which rarely get filled. Water quality, especially excess of fluoride concentration in groundwater, is a major concern in the study area. In as many as 1122 habitations in Ranga Reddy and Nalgonda districts, fluorosis is prevalent and they have fluoride content in excess of $1.5 \mathrm{mg} / \mathrm{l}$ drinking water.

\subsection{Location}

The area under investigation lies in between the longitude $79^{\circ} 00^{\prime}$ $79^{\circ} 30^{\prime} \mathrm{E}$ and latitude $16^{\circ} 45^{\prime}-17^{\circ} 15^{\prime} \mathrm{N}$. The study area is located in and around Nalgonda town in Nalgonda district, Telangana state. For the detailed investigation of the occurrence, movement and quantity of the groundwater an area of about 2880 sq.km. in Narkatpalli, Chityal, Katangur, Nakrekal etc. mandals have been selected. The location map of the study area is shown in Fig.1. 


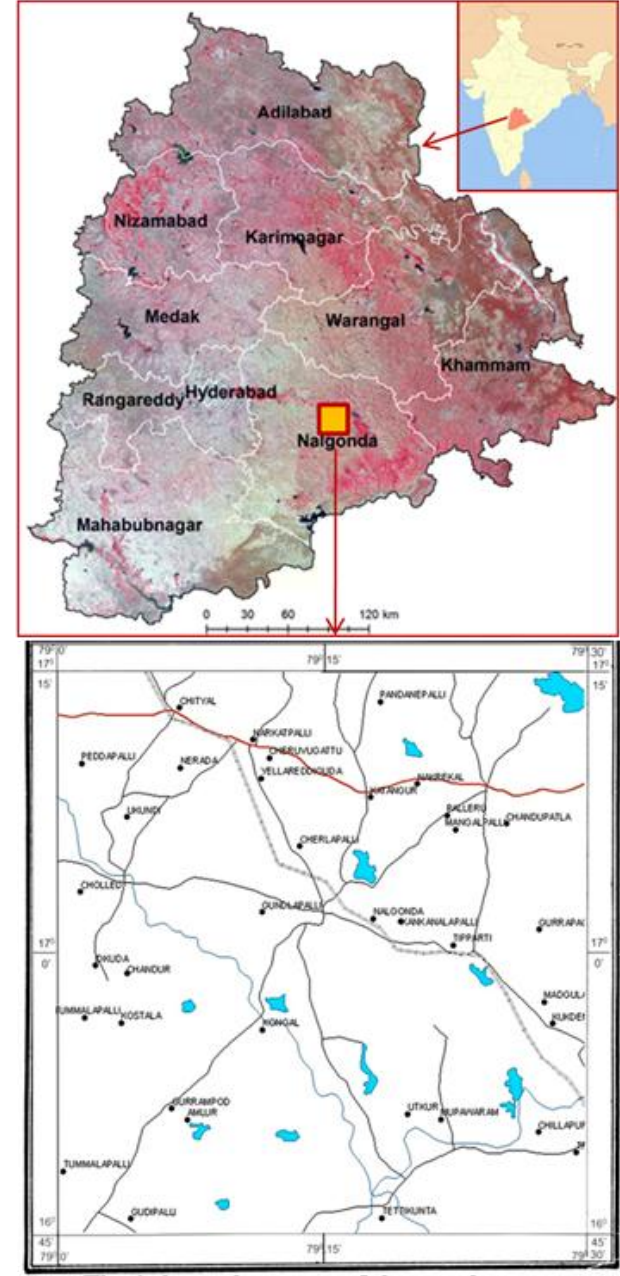

Fig.1: Location map of the study area
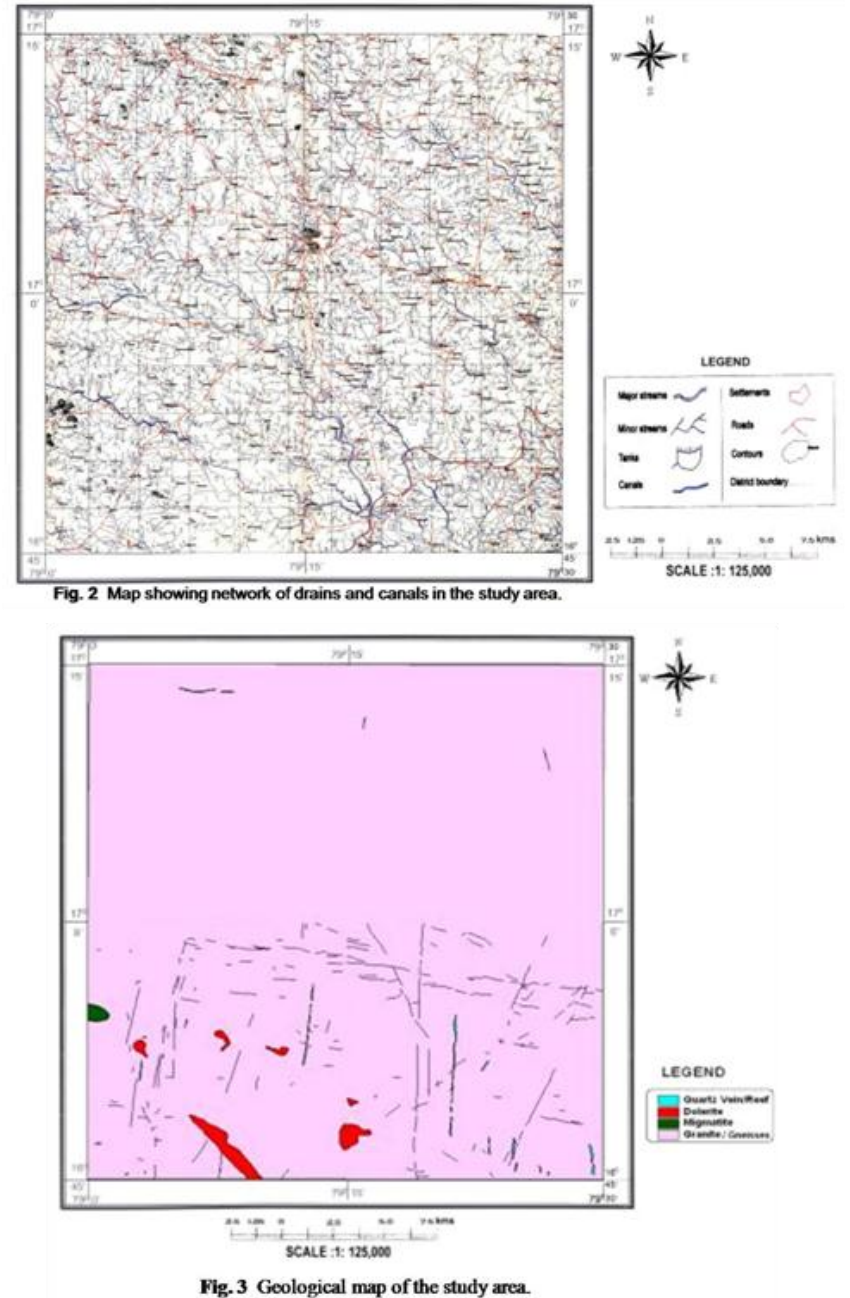

\begin{tabular}{|c|c|c|c|}
\hline Age & Super group & Group & Lithology \\
\hline \multirow[t]{2}{*}{$\begin{array}{l}\text { Recent to } \\
\text { Sub recent } \\
\text { Proterozoic }\end{array}$} & Kurnool & $\begin{array}{l}\text { Jammalamadugu } \\
\text { Banaganapalli }\end{array}$ & $\begin{array}{c}\text { Soil and } \\
\text { Alluvium } \\
\text { Nargi limestones and shales } \\
\text { Quartzites and conglomerates }\end{array}$ \\
\hline & Cuddapah & Krishna & Srisailam quartrites and shales \\
\hline \multirow{4}{*}{ Archaeans } & $\begin{array}{l}\text { Younger } \\
\text { intrusives }\end{array}$ & & $\begin{array}{l}\text { Quartz reefs, dolerites, pegmatites, } \\
\text { quartz veins, pink granites and } \\
\text { other ultra basics }\end{array}$ \\
\hline & Dharwar & & $\begin{array}{l}\text { Chlorite, hornblende schists and } \\
\text { granulites }\end{array}$ \\
\hline & $\begin{array}{l}\text { Peninsular } \\
\text { Gneissic } \\
\text { complex }\end{array}$ & & $\begin{array}{l}\text { Grey granites, gneisses and } \\
\text { migmatites }\end{array}$ \\
\hline & $\begin{array}{c}\text { Older } \\
\text { metamorphics }\end{array}$ & & $\begin{array}{l}\text { Biotite schists } \\
\text { Pyroxenites and amphibolites }\end{array}$ \\
\hline
\end{tabular}

\subsection{Drainage}

There are no perennial streams in the study area. The Palleru river, which is ephemeral in nature, drains from northwest to southeast traversing through the area. Many $1^{\text {st }}$ to $3^{\text {rd }}$ order streams are joining to the main river course. The drainage is medium to coarse textured and dendritic to sub dendritic type, which is characteristic of hard rock terrain and develops in regions of homogeneity [2]. The drainage is mostly structurally controlled and draining through the joints and fractures. The drainage is mainly from northwest to southeast. The shallow valley fill material, mainly sandy in nature underlies the river bed and hence forms very good media for infiltration of rain water to recharge the aquifer. The drainage map shown in the Fig. 2. 


\section{Geology of the Study Area}

Geologically the study area forms a part of the Indian peninsular shield and comprises Archaean and Proterozoic formations characterised by the basement complex or the Peninsular gneissic complex rocks. The oldest known geological formations are the Archaeans which are deposited in shallow basins and subsequently intruded by basic rocks. The gneisses and granites were subsequently intruded by dykes of dolerite and veins of pegmatite and quartz, Fig. 3 shows the geological map of the study area

The study area has been characterised by the rocks belonging to both Archaean and Proterozoic formations. The Proterozoic formations which are also known as Cuddapah formations.

The present study area covers around 2880 Sq.kms. and stretches along the northern bank of the Krishna river. The study area is mostly rugged granitic plain which descends towards southeast, where the altitude of the hills ranges from $635 \mathrm{~m}$ (in the north-west) to $128 \mathrm{~m}$ (in the southeast).

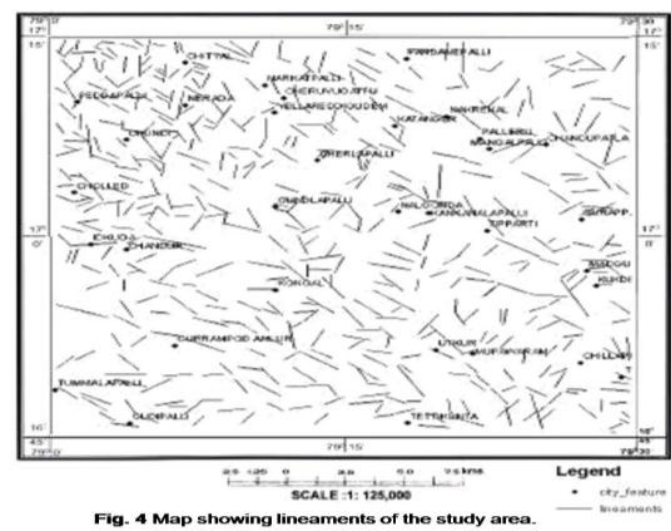

The chosen area is underlain by crystalline rocks and consists of Peninsular gneissic complex i.e. pink and grey varieties of granites and granitic gneisses of Archaean age. The pink and grey granites are intruded by dolerite dykes and followed by injection of quartz, feldspar, pegmatite and epidote veins. Dolerite dykes mark the last period of igneous activity. There have also recent alluvial deposits in the area. They are confined to the valleys between the hill ranges as valley fill deposits and the flood plains of Hallia and Konagal rivers and also to the narrow thin patches along the streams. The stratigraphic succession of these rocks is shown in Table 1, [3].

\subsection{Stratigraphic succession}

The greater part of the area occupied by the Peninsular gneissic complex is of Archaean age. A generalised succession can be described as follows

\section{Materials and Methods}

\subsection{Hydrogeology}

The groundwater occurrence is dependent upon various factors including the lithology, geomorphology, rainfall, drainage etc. The movement of groundwater through crystalline rocks is one of the least predictable phenomena in all of groundwater science, because the porosity of these rocks, is very low and the permeability is usually controlled by an irregular network of streams. Since these Archaean group of rocks are practically devoid of primary porosity, the occurrence and movement of groundwater are mainly controlled by the nature, degree and depth of weathering and in fluenced by the presence of secondary structures like fractures, joints etc. When fractures control the permeability of the rock, the permeability will be anisotropic, with higher conductivity parallel to prominent fracture sets. The permeability of a fracture is controlled by its aperture and smoothness, properties that are near impossible to measure at the depth [4].

\subsection{Nature of Aquifer}

The groundwater condition of the aquifers which are existing in the study area have been evaluated with respect to the depth to water table and groundwater fluctuation. The data presented is mainly from well inventory studies.

\subsection{Area of Peninsular Gneissic Complex (Granites and Gneisses)}

Geomorphologically these areas come under the unit of shallow weathered buried pediplain and moderately weathered buried pediplain. Groundwater conditions in Peninsular gneissic complex (granites and gneisses) of the study area is indicated as depth to water table and seasonal fluctuations.

These areas of Peninsular gneissic complex (granites and gneisses) are generally poor aquifers, yet they are suitable for construction of dug wells, dug cum bore wells and bore wells. Groundwater is exploited in this zone mainly by dug wells which are used for domestic purposes and a few wells are used for irrigation. Many of these wells are operated by electrical or oil engines with capacities in the range of 2.5 H.P to 5 H.P.

\section{Results and discussion}

\subsection{Lineaments}

The lineaments in the study area are present in different directions with different lengths. Fig.5 shows that the majority of lineaments having the trend $\mathrm{N} 20^{\circ} \mathrm{W}$ to E-W, with $52.94 \%$ of lineaments are found in this direction.

In the north eastern direction the major set of lineament trend $\mathrm{N} 20^{\circ} \mathrm{E}$ to $\mathrm{E}-\mathrm{W}$ with $43.05 \%$ of lineaments are found in this direction. Apart from this some of the lineaments trends N-S direction i.e., $3 \%$ and $\mathrm{E}-\mathrm{W}$ direction with $2 \%$.

A map of the entire area of study has been drawn, indications areas of high, moderate and low density lineaments based on the studies on lineament density (Fig. 4).

\subsection{Water table Configuration}

The configuration of the water table in the study area has been inferred, using the data collected by measuring the groundwater level in 94 wells. The well locations have been shown in the Fig5, $[3] .$.
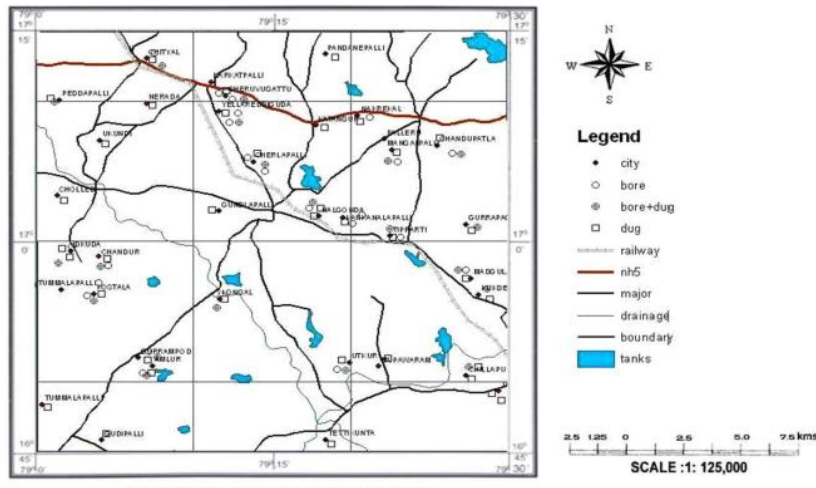

Fig. 5 Well location map of the study area 


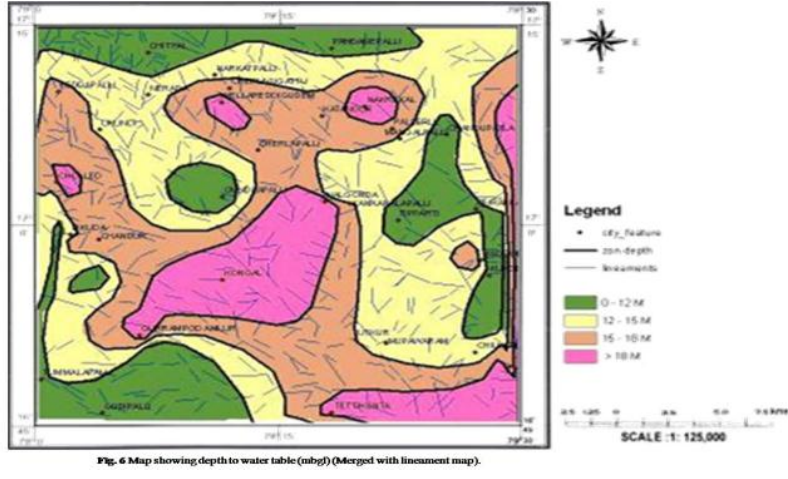

Fig. 6 Map showing depth to water table (mbgl) (Merged with lineament map).

The groundwater level varies from $0 \mathrm{mbgl}$ to $19 \mathrm{mbgl}$. Based on this data, the study area has been classified into 4 categories as mentioned below (Fig.6).

\section{Category}

I
II
III
IV

IV

\section{Configuration}

wells with $0-12 \mathrm{mbgl}$ wells with $12-15 \mathrm{mbgl}$ wells with 15-18 mbgl wells with $>18 \mathrm{mbgl}$

\subsubsection{Category I ( 0 - $12 \mathrm{~m})$}

The wells belonging to this category have been identified to be situated around the villages namely Chityal, Kostala, Amlur, Chandupatla, Tipparti, Kukadem, Gundlapalli. The details of the wells of this category have been shown in the Table 2. Majority of the wells belonging to this category are showing an average water table depth of $8.0 \mathrm{mbgl}-12.0 \mathrm{mbgl}$

Geomorphologically all the wells are belonging to this category are located in all the places of the study area, which is characterized as undulating plain.

The lineament pattern with reference to the occurrence of these wells indicate majority of the wells are away from the lineament occurrence. The lack of lineament occurrence and high altitude of the area resulted a deep water table (Fig.. 7).

\subsubsection{Category II (12 -15 m)}

Table 2: Water table configuration

\begin{tabular}{|c|c|c|c|c|}
\hline \multicolumn{5}{|c|}{ Category- I (0-12 m) Average depths } \\
\hline $\begin{array}{c}\text { Name of the } \\
\text { Village }\end{array}$ & $\begin{array}{l}\text { No.of } \\
\text { wells }\end{array}$ & $\begin{array}{c}\text { Dug } \\
\text { wells }\end{array}$ & $\begin{array}{c}\text { Depth to } \\
\text { water level } \\
\text { (pre monsoon) }\end{array}$ & $\begin{array}{c}\text { Depth to } \\
\text { water level } \\
\text { (post mon- } \\
\text { soon) }\end{array}$ \\
\hline Chityal & 3 & 1 & 11.8 & 10.5 \\
\hline Kostala & 3 & 1 & 12.0 & 10.5 \\
\hline Amlur & 3 & 1 & 9.8 & 8.2 \\
\hline Chandupatla & 3 & 1 & 12.0 & 11.0 \\
\hline Tipparti & 3 & 1 & 11.8 & 9.9 \\
\hline Kukadem & 2 & 1 & 9.0 & 8.0 \\
\hline Gundlapalli & 2 & 1 & 11.0 & 10.0 \\
\hline
\end{tabular}

In this category the wells having $12 \mathrm{mbgl}$ to $15 \mathrm{mbgl}$ depth have been grouped together. Majority of these wells are located in the villages namely Cheruvugattu, Nalgonda, Cherlapalli, Idkuda, Chandur, Mangalapalli, Kankanalapalli, Madugulapalli, Utkur, Chillapur, Tummalapalli, Gudipalli, Peddapalli, Ukundi, Gurrapagudem, Mupawaram, Katangur, Nerada and Pandanepalli. Majority of the wells are showing the depth to water level average range $10.9 \mathrm{mbgl}$ to $15 \mathrm{mbgl}$. The data for this category is shown in Table 3.
Geomorphologically this category of wells also confined to the plain areas and majority of wells are located in all the places of the study area of the undulating areas.

The study of lineament pattern of this area, shows the fact that the lineament network has much influence on the groundwater occurrence and indicate that the lineaments have enhanced the chance of groundwater occurrence at much shallow levels, besides their influence on the formation of weathered and semi weathered zones, for aquifer localisation in the subsurface (Fig.8).

\subsubsection{Category III (15 - $18 \mathrm{~m})$}

In this category, wells belonging to $15 \mathrm{mbgl}$ to $18 \mathrm{mbgl}$ have been grouped together. These wells are noted to occur around the villages namely Yellareddiguda, Gurrampod, Tripurawaram, Cholled, Tettikunta, Kankanalapalli, Cholled, Pandanepalli, Tettikunta, Tripurawaram and Kostala. The data Table 4 indicate that the majority of wells are having an average range of $14.3 \mathrm{mbgl}$ to 18.0 $\mathrm{mbgl}$. However, the number of dug wells in this category are very few (08) and majority of the wells are bore wells.

Table 3: Water table configuration

\begin{tabular}{|c|c|c|c|c|}
\hline \multicolumn{5}{|c|}{ Category- II (12-15 m) Average depths } \\
\hline $\begin{array}{c}\text { Name of the } \\
\text { Village }\end{array}$ & $\begin{array}{l}\text { No.of } \\
\text { wells }\end{array}$ & $\begin{array}{l}\text { Dug } \\
\text { wells }\end{array}$ & $\begin{array}{c}\text { Depth to } \\
\text { water level } \\
\text { (pre monsoon) }\end{array}$ & $\begin{array}{c}\text { Depth to } \\
\text { water level } \\
\text { (post monsoon) }\end{array}$ \\
\hline Cheruvugattu & 4 & 1 & 14.7 & 12.9 \\
\hline Nalgonda & 4 & 1 & 13.2 & 12.1 \\
\hline Cherlapalli & 4 & 1 & 15 & 13 \\
\hline Idkuda & 4 & 1 & 12 & 11 \\
\hline Chandur & 3 & 1 & 15 & 13 \\
\hline Mangalapalli & 3 & 1 & 13.7 & 11.9 \\
\hline Kankanalapalli & 3 & 1 & 14.5 & 12.9 \\
\hline Madugulapalli & 3 & 1 & 15 & 14 \\
\hline Utkur & 3 & 1 & 14.5 & 13.4 \\
\hline Chillapur & 4 & 1 & 13 & 11 \\
\hline Chillapur & 4 & 1 & 14.3 & 12.8 \\
\hline Tummalapalli & 2 & 1 & 12.8 & 10.9 \\
\hline Gudipalli & 2 & 1 & 12 & 11 \\
\hline Peddapalli & 2 & 1 & 15 & 13 \\
\hline Ukundi & 2 & 1 & 14 & 13 \\
\hline Gurrapagudem & 3 & 1 & 12.8 & 10.9 \\
\hline Mupawaram & 2 & 1 & 13 & 12 \\
\hline Katangur & 2 & 1 & 15 & 14 \\
\hline Nerada & 2 & 1 & 13.7 & 11.9 \\
\hline Pandanepalli & 2 & 1 & 12.6 & 11.4 \\
\hline
\end{tabular}




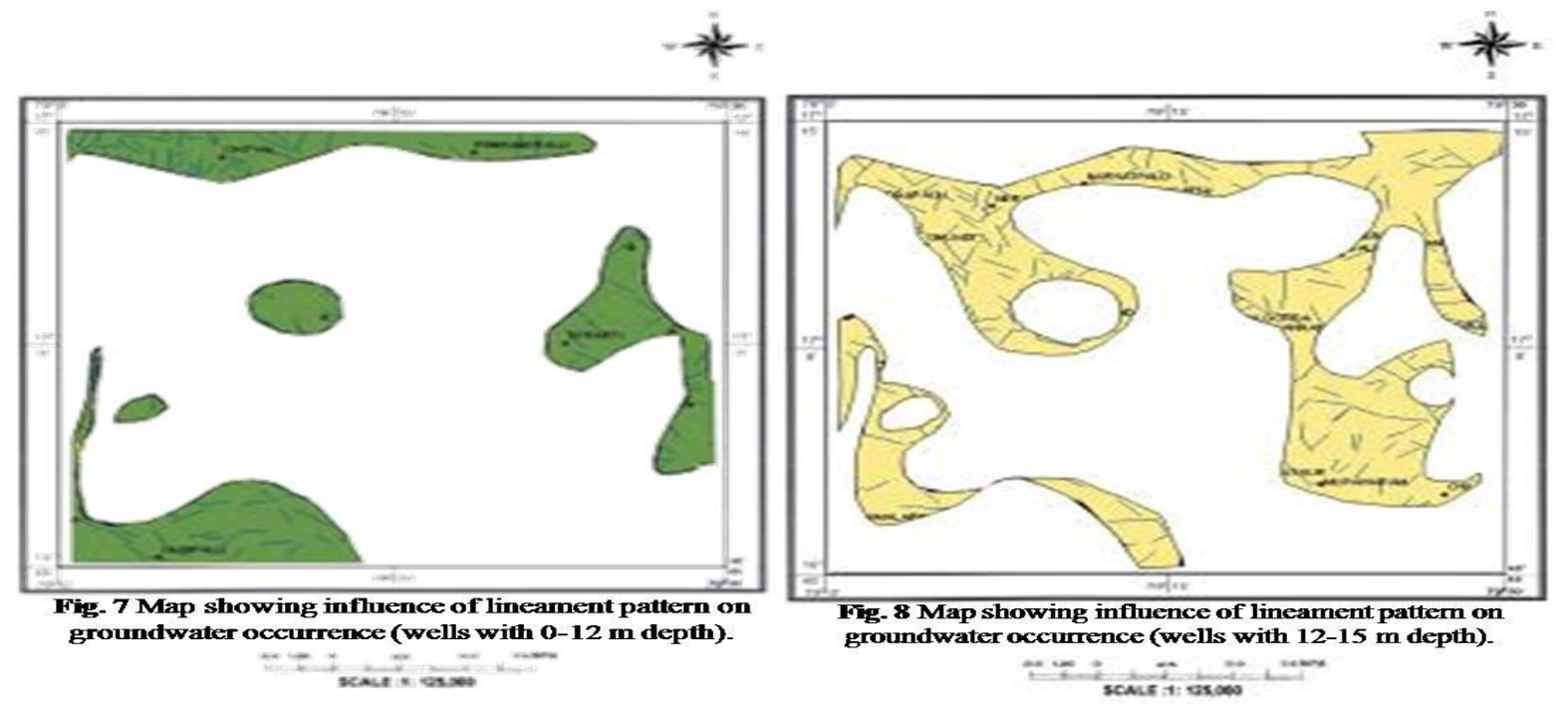

Table 4: Water table configuration

\begin{tabular}{|c|c|c|c|c|}
\hline \multicolumn{5}{|c|}{ Category- III (15-18 m) Average depths } \\
\hline $\begin{array}{c}\text { Name of the } \\
\text { Village }\end{array}$ & $\begin{array}{c}\text { No. } \\
\text { of } \\
\text { wells }\end{array}$ & $\begin{array}{c}\text { Dug } \\
\text { wells }\end{array}$ & $\begin{array}{c}\text { Depth to water } \\
\text { level } \\
\text { (pre monsoon) }\end{array}$ & $\begin{array}{c}\text { Depth to water } \\
\text { level } \\
\text { (post monsoon) }\end{array}$ \\
\hline Yellareddiguda & 4 & 1 & 17.8 & 15.9 \\
\hline Gurrampod & 4 & 1 & 17.7 & 15.8 \\
\hline Tripurawaram & 3 & 1 & 16.8 & 15.4 \\
\hline Cholled & 2 & 1 & 17 & 15 \\
\hline Tettikunta & 2 & 1 & 16.8 & 14.9 \\
\hline Kankanalapalli & 3 & 1 & 17.5 & 14.3 \\
\hline Cholled & 2 & 1 & 17 & 14.8 \\
\hline Pandanepalli & 2 & 1 & 17.7 & 15.3 \\
\hline Tettikunta & 2 & 1 & 18 & 17.2 \\
\hline Tripurawaram & 3 & 1 & 16 & 15.8 \\
\hline Kostala & 4 & 1 & 19 & 17.5 \\
\hline
\end{tabular}

\subsection{Water table Fluctuation}

Fluctuations of water table in the study area has been measured for 47 wells based on this data the wells have been classified into 4 categories. These fluctuations have been depicted in the Fig.11., [3].

\section{Category}

I

II

III

IV

\section{Fluctuation}

Ground water Fluctuation $<1 \mathrm{~m}$ Ground water Fluctuation $1-2 \mathrm{~m}$ Ground water Fluctuation $2-3 \mathrm{~m}$ Ground water Fluctuation $>3 \mathrm{~m}$

The formation of alluvium at some places are observed. Geomorphologically, the area can be categorised as undulating plain and the majority of wells are situated in the northern portion of study area.

The distribution of lineament pattern with reference to the location of wells of this category indicate that, the lineament occurrence in this zone has shown a decreasing trend when compared to the earlier category (Fig.9). This clearly confirm the observation that the groundwater configuration has been influenced by the lineament pattern, besides the other factors namely lithology and geomorphology.

\subsubsection{Category IV ( > 18m)}

In this category the wells which are characterised by very deep water table $(>18 \mathrm{mbgl})$. These deeper water table wells are located to occur around the villages namely Nalgonda, Konagal, Nakrekal, Tipparti, Idkuda, Chillapur, Cheruvugattu and Gurrampod. About 08 dug wells have been identified in this category and majority are bore wells. The data indicated in Table 5, and the average depth to water level range from $15.1 \mathrm{~m}$ to $19.0 \mathrm{~m}$.

The location of these wells are around northern part. The lineament pattern indicates that, the occurrence of lineaments in this area belonging to this category is very rare. The occurrence of deep water levels can be explained by the lack of lineament pattern. The well locations are shown in the Fig.10.

\subsubsection{Category I ( $<1 \mathrm{~m})$}

In this category about 10 wells have been identified. These wells are located in the villages namely Nalgonda, Idkuda, Konagal, Chandupatla, Kukadem, Gudipalli, Ukundi, Mupawaram, Gundlapalli and Katangur majority of these wells are dug wells. The data indicate most of the wells show average fluctuation in the range of $0 \mathrm{~m}$ to $01 \mathrm{~m}$ (Table 6).

The wells of this category have been identified mainly in the eastern, southern, southeastern regions

Geomorphologically, all these wells are mainly confined to the undulating plain with exception of very few wells.

The relationship between the lineament pattern and the positioning of wells confirm that the area has high density of lineaments. This aspect can also be realised in the Fig. 12.

\subsubsection{Category II (1- 2 m)}

In this category about 27 wells have been identified (1-2 m). The wells are situated in and around villages namely Chityal, Cheruvugattu, Yellareddiguda, Nalgonda, Cherlapalli, Kostala, Gurrampod, Amlur, Nakrekal, Mangalapalli, Kankanalapalli, Tipparti, Madugulapalli, Utkur, Tummalapalli, Peddapalli, Gurrapagudem, Tripurawaram, Nerada, Pandanepalli, Tettikunta, Idkuda, Chandur, Chillapur and Cholled. The average range of fluctuation in this category has been observed which is in the range of $1.1 \mathrm{~m}$ to $2.0 \mathrm{~m}$ Table 7 .

Majority of the wells investigated, belong to this category are located in the central as well as northern regions of the 
study area. Lithologically the rock types are mainly Peninsular gneissic complex.

Geomorphologically, majority of these wells are confined to the plains and a few wells are confined to undulating plain.

The lineament pattern in relation to the fluctuation indicated that the density of lineaments localised in this area is less, when compared to the earlier

category. However, majority of the lineaments of the earlier category are also extending into this category. In other words, these two categories can be called as a gradual transformation from a low fluctuation zone to the fluctuation upto $2 \mathrm{~m}$. This aspect can also be realised from the Fig. 13.

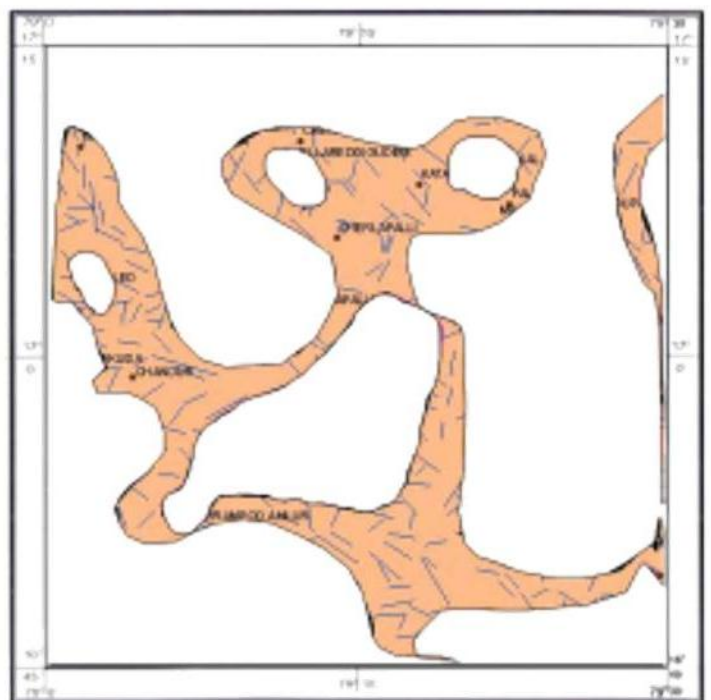

Fig. 9 Map showing influence of lineament pattern on groundwater occurrence (wells with 15-18 $\mathrm{m}$ depth).

\subsubsection{Category III (2- $3 \mathrm{~m})$}

In this category the wells having the fluctuation of groundwater table in the range of $2 \mathrm{~m}$ to $3 \mathrm{~m}$ have been grouped together. About 05 wells have been investigated, these wells are located in the villages namely Idkuda, Cholled, Chillapur, Pandanepalli and Nalgonda. These wells form very small number when compare to earlier two categories (Table 8).

Geomorphologically, the wells are located mainly in undulatory. The location of these wells with referene to the lineaments indicate that the lineaments have little or no influence on these areas, as shown in Fig. 14.

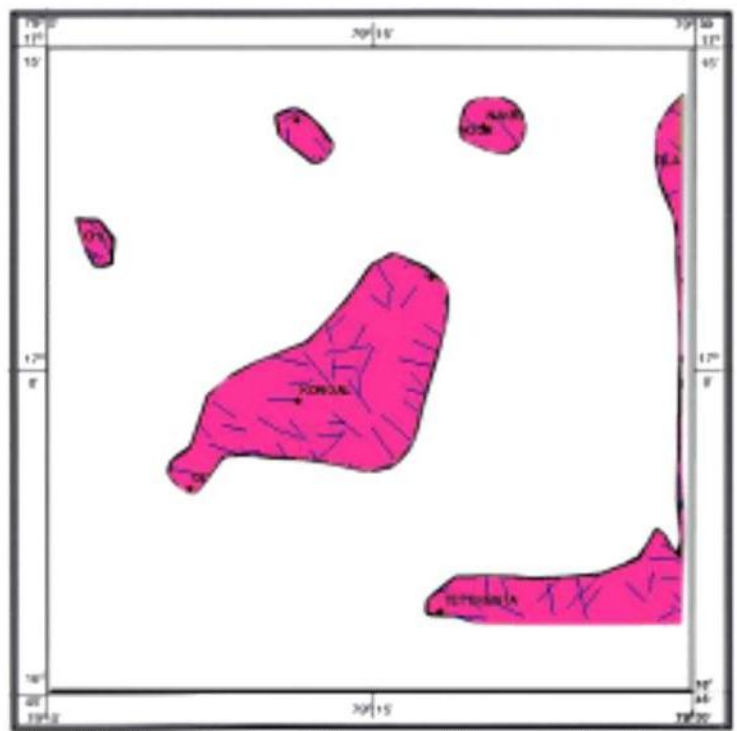

Fig. 10 Map showing influence of lineament pattern on groundwater occurrence (wells with $>18 \mathrm{~m}$ depth).
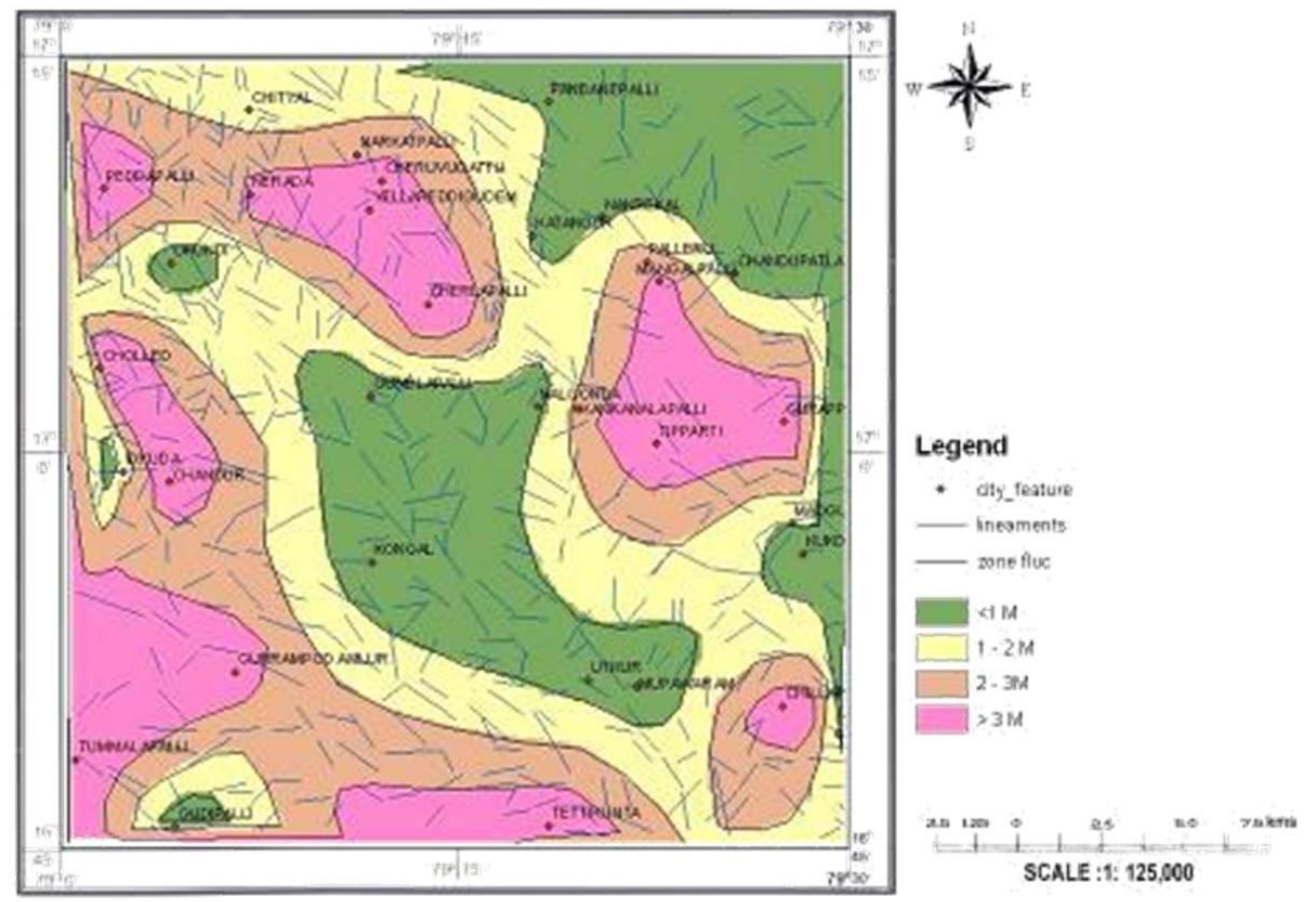

Fig. 11 Map showing seasonal water table fluctuation (mbgl)

(Merged with lineament map) 


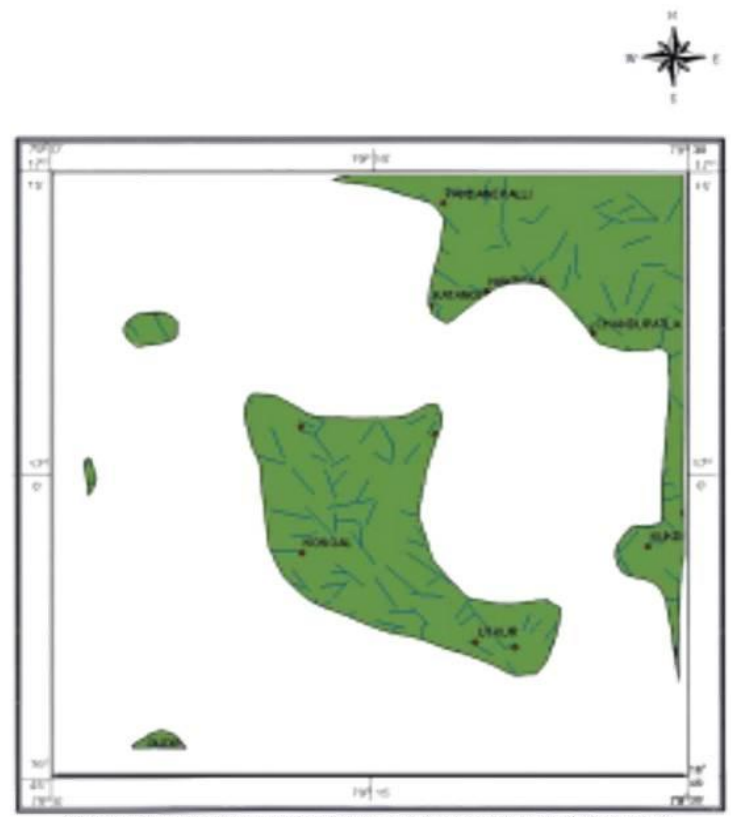

Fig. 12 Map showing gronndwater fluctuation as influenced by lineament pattern (wells with $<1 \mathrm{~m}$ fluctuation).

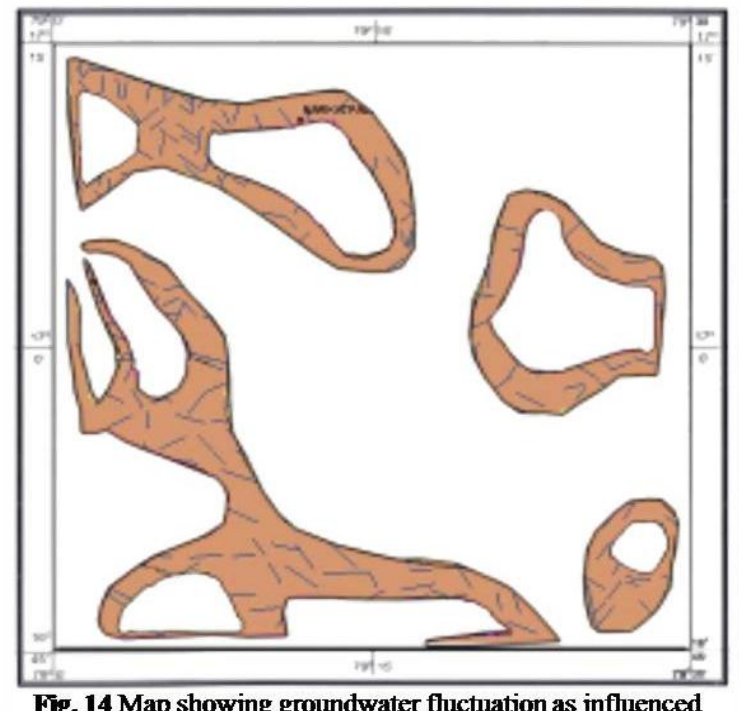

Fig. 14 Map showing groundwater fluctuation as influenc by lineament pattem (wells with 2-3 $\mathrm{m}$ fluctuation).

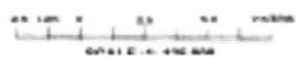

\subsubsection{Category IV (> $3 \mathrm{~m})$}

In this category the wells having very high fluctuation over of more than $3 \mathrm{~m}$ have been grouped together. However only 05 wells of this category were identified. They are located in the villages namely Tettikunta, Gurrampod, Tipparti, Kankanalapalli and Nerada (Table 9).

It is observed that the above mentioned areas are devoid of any lineament and so the wells are not influenced, as shown in Fig. 15

It is interesting to observe that the areas having fluctuations from $>1 \mathrm{~m}$ to $2 \mathrm{~m}$ (first two categories) predominate the study area. The wells in the areas belonging to these two categories seem to be in transitional (midway) form. Wells having fluctuations from $2 \mathrm{~m}$ to $3 \mathrm{~m}$ and more, are present adjacent to the above, showing inter-relationship with them. In other words they all belong to the same hydrogeological environment

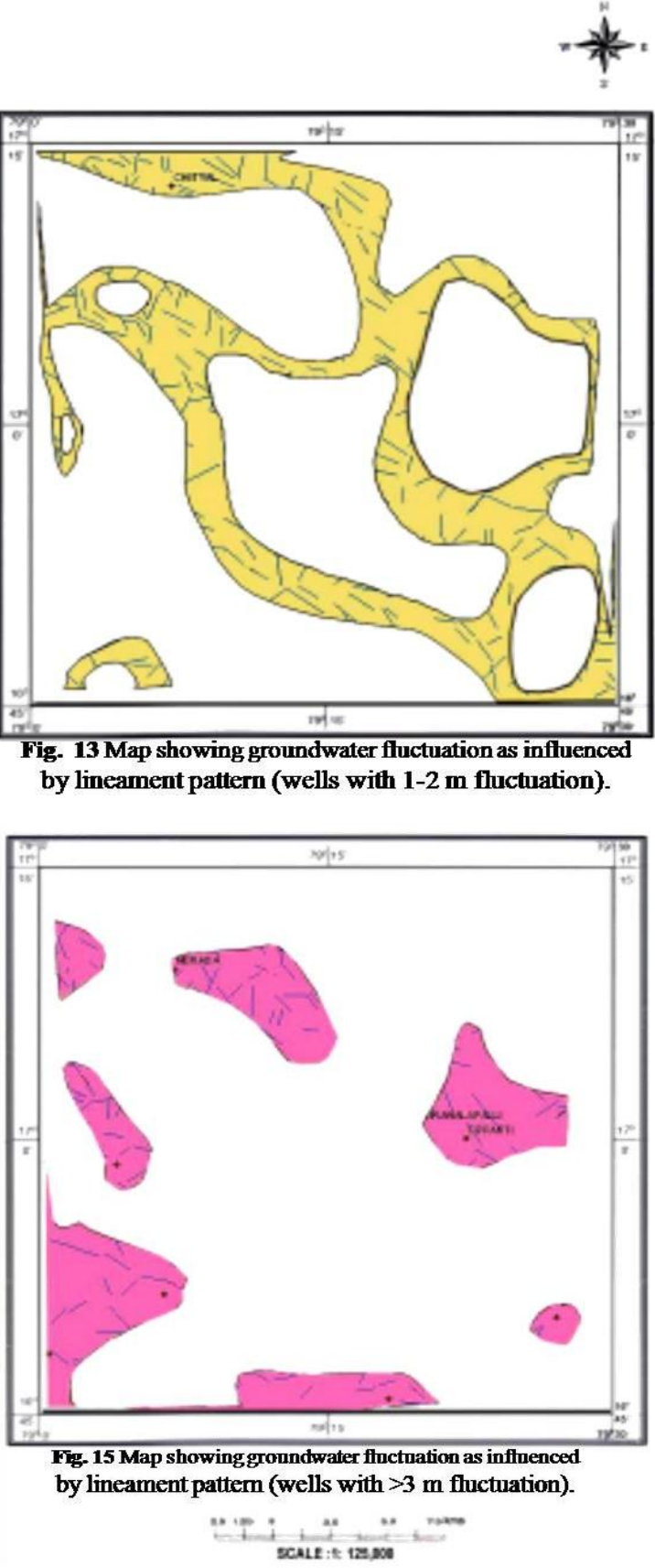

Table 6 Water level fluctuation

\begin{tabular}{|l|c|c|c|c|c|}
\hline $\begin{array}{c}\text { Name of the } \\
\text { village }\end{array}$ & $\begin{array}{c}\text { No.of } \\
\text { wells }\end{array}$ & $\begin{array}{c}\text { Dug } \\
\text { wells }\end{array}$ & $\begin{array}{c}\text { Depth to } \\
\text { water } \\
\text { level } \\
\text { (pre } \\
\text { monsoon) }\end{array}$ & $\begin{array}{c}\text { Depth to } \\
\text { water level } \\
\text { (post mon- } \\
\text { soon) }\end{array}$ & Fluctuation \\
\hline Nalgonda & 4 & 1 & 19 & 18 & 1 \\
\hline Idkuda & 4 & 1 & 12 & 11 & 1 \\
\hline Konagal & 3 & 1 & 19 & 18 & 1 \\
\hline Chandupatla & 3 & 1 & 12 & 11 & 1 \\
\hline Kukadem & 2 & 1 & 9 & 8 & 1 \\
\hline Gudipalli & 2 & 1 & 12 & 11 & 1 \\
\hline Ukundi & 2 & 1 & 14 & 13 & 1 \\
\hline Mupawaram & 2 & 1 & 13 & 12 & 1 \\
\hline Gundlapalli & 2 & 1 & 11 & 10 & 1 \\
\hline Katangur & 2 & 1 & 15 & 14 & 1 \\
\hline
\end{tabular}


Table 7 Water level fluctuation Category - II ( 1-2 m) Average depths

\begin{tabular}{|c|c|c|c|c|c|}
\hline $\begin{array}{l}\text { Name of the } \\
\text { village }\end{array}$ & $\begin{array}{l}\text { No. of } \\
\text { wells }\end{array}$ & $\begin{array}{c}\text { Dug } \\
\text { wells }\end{array}$ & $\begin{array}{c}\text { Depth to } \\
\text { water level } \\
\text { (pre monsoon) }\end{array}$ & $\begin{array}{c}\text { Depth to } \\
\text { water level } \\
\text { (post monsoon) }\end{array}$ & Fluctuation \\
\hline Chityal & 3 & 1 & 11.8 & 10.5 & 1.3 \\
\hline Yellareddiguda & 4 & 1 & 17.8 & 15.9 & 1.9 \\
\hline Nalgonda & 4 & 2 & 13.2 & 12.1 & 1.1 \\
\hline Cherlapalli & 4 & 1 & 15 & 13 & 2 \\
\hline Kostala & 3 & 1 & 12 & 10.5 & 1.5 \\
\hline Gurrampod & 4 & 1 & 17.7 & 15.8 & 1.9 \\
\hline Amlur & 3 & 1 & 9.8 & 8.2 & 1.6 \\
\hline Nakrekal & 2 & 1 & 18.6 & 17.4 & 1.2 \\
\hline Mangalapalli & 3 & 1 & 13.7 & 11.9 & 1.8 \\
\hline Kankanalapalli & 3 & 1 & 14.5 & 12.9 & 1.6 \\
\hline Tipparti & 3 & 1 & 11.8 & 9.9 & 1.9 \\
\hline Madugulapalli & 3 & 1 & 15.5 & 14.3 & 1.2 \\
\hline Utkur & 3 & 1 & 14.5 & 13.4 & 1.1 \\
\hline Peddapalli & 2 & 1 & 15 & 13 & 2.0 \\
\hline Gurrapagudem & 3 & 1 & 12.8 & 10.9 & 1.9 \\
\hline Tripurawaram & 3 & 1 & 17.8 & 16.4 & 1.4 \\
\hline Tripurawaram & 3 & 1 & 15.8 & 14.6 & 1.2 \\
\hline Nerada & 2 & 1 & 13.7 & 11.9 & 1.8 \\
\hline Pandanepalli & 2 & 1 & 12.6 & 11.4 & 1.2 \\
\hline Tettikunta & 2 & 1 & 16.8 & 14.9 & 1.9 \\
\hline Idkuda & 4 & 1 & 18.2 & 16.7 & 1.5 \\
\hline Chandur & 3 & 1 & 15.7 & 13.8 & 1.9 \\
\hline Chillapur & 4 & 1 & 13 & 11 & 2.0 \\
\hline Chillapur & 4 & 1 & 14.3 & 12.8 & 1.5 \\
\hline Cholled & 2 & 1 & 17.0 & 15.0 & 2.0 \\
\hline
\end{tabular}

Table 8 Water level fluctuation

Category - III (2-3m) Average depths

\begin{tabular}{|c|c|c|c|c|c|}
\hline $\begin{array}{c}\text { Name of the } \\
\text { village }\end{array}$ & $\begin{array}{l}\text { No.of } \\
\text { wells }\end{array}$ & $\begin{array}{c}\text { Dug } \\
\text { wells }\end{array}$ & $\begin{array}{c}\text { Depth to } \\
\text { water level } \\
\text { (pre monsoon) }\end{array}$ & $\begin{array}{c}\text { Depth to } \\
\text { water level } \\
\text { (post monsoon) }\end{array}$ & Fluctuation \\
\hline Idkuda & 4 & 2 & 18.6 & 15.7 & 2.9 \\
\hline Cholled & 2 & 1 & 17.0 & 14.8 & 2.2 \\
\hline Chillapur & 4 & 2 & 18.3 & 16 & 2.3 \\
\hline Pandanepalli & 2 & 1 & 17.7 & 15.3 & 2.4 \\
\hline Nalgonda & 4 & 2 & 17.5 & 15.3 & 2.2 \\
\hline
\end{tabular}

Table 9 Water level fluctuation

Category - IV ( > $3 \mathrm{~m}$ ) Average depths

\begin{tabular}{|l|c|c|c|c|}
\hline $\begin{array}{c}\text { Name of the } \\
\text { village }\end{array}$ & $\begin{array}{c}\text { No. of } \\
\text { wells }\end{array}$ & $\begin{array}{c}\text { Dug } \\
\text { wells }\end{array}$ & $\begin{array}{c}\text { Depth to } \\
\text { water level } \\
\text { (pre monsoon) }\end{array}$ & $\begin{array}{c}\text { Depth to } \\
\text { water level } \\
\text { (post monsoon) }\end{array}$ \\
\hline Tettikunta & 2 & 1 & 17.2 & 13.9 \\
\hline Gurrampod & 3 & 1 & 18.5 & 15.4 \\
\hline Tipparti & 3 & 1 & 19.0 & 15.8 \\
\hline Kankanalapalli & 3 & 1 & 17.5 & 3.1 \\
\hline Nerada & 2 & 1 & 18.2 & 3.2 \\
\hline
\end{tabular}

\subsection{Comparison between the Groundwater Configura- tion and Fluctuation}

As mentioned in the earlier paragraph the area of investigation has been characterised by wells with distinct groundwater characteristics. The water table condition in the study area revealed that, it has been characterised by its configuration and fluctuation. The Fig.4.3 and Fig.4.8 respectively give the water table configuration and fluctuation data in pictorial form.

It is interesting to note that there has been a good relationship between the groundwater configuration and groundwater fluctuation of the area. It can be established that majority of the very shallow and shallow wells have fluctuations within the range of 0 $\mathrm{m}-2 \mathrm{~m}$. Similarly, the moderately deep and deep wells can be specially correlated with wells having fluctuation from $2 \mathrm{~m}$ to more than $3 \mathrm{~m}$ ( $3 \mathrm{rd}$ and $4^{\text {th }}$ categories). In other words the shallow wells have low fluctuation and deep wells have high fluctuation.

\section{Conclusions}

- The study area is characterised by the occurrence of wells under different depth categories $(0-12 \mathrm{~m}, 12-15 \mathrm{~m}, 15-18 \mathrm{~m}$ and $>18$ $\mathrm{m})$. It is observed that the majority of the wells occur in 12-15 $\mathrm{m}$ depth category and less number of wells occur in $0-12 \mathrm{~m}$ depth category

- The deeper wells mainly occur or observed to occur in the central and southeastern parts of the study area whereas the shallow wells are confined to northern, eastern and southeastern parts of the study area.

- As far as the water table fluctuation is concerned the Central part of the study area is characterised by low fluctuation where- 
as the North western, South western and Eastern parts are characterised by high water table fluctuation. The important observation is that the deeper wells are having low fluctuation whereas the shallow wells are characterised by high fluctuation and high density lineaments.

- As far as the lineament pattern is concerned the highest lineament density occur in the northwestern part followed by moderate lineament density in southeastern and northeastern parts. The southwestern part show relatively less number of lineaments.

- Groundwater occurs in the study area under water table and semi-confined conditions limited to weathered and fractured zones. The zone of weathering ranges from $0 \mathrm{~m}$ (near inselbergs) to $17 \mathrm{~m}$. The joints and fractures, which act as conduits for the movement of groundwater are responsible for the good yield of water from the wells.

\section{Acknowledgement}

I express my sincere thanks to The Principal and Management of S.R.K.R.Engineering College (Autonomous), Bhimavaram, W.G.District, Andhra Pradesh, India, for their support in carrying out of this work.

\section{References}

[1] Shiklomanov, I.A. (1998). World water resources. A new appraiser and assessment for the $21^{\text {st }}$ Centuary, Paris-UNESCO.

[2] Srivastav, S.K. and Bhattacharya, A, Remote Sensing in Lithological and Structural Mapping. Presented at National Workshop on Role of Remote Sensing in Groundwater prospecting, (1991), 4-5 ${ }^{\text {th }}$ Sept.1991, NRSA, Hyderabad.

[3] Ganesh K.M., "A Study on geology, hydrogeology and quality of fluoride bearing groundwater regime from parts of Nalgonda district, A.P, using Remote sensing and G.I.S. Tools" Andhra University, Visakhapatnam, A.P. (2011).

[4] S.P.Rajaveni, et.al., Geological and geomorphological controls on groundwater occurrence in a hard rock region, Appl. Water Sci. Springerlink.com, $\left(5^{\text {th }}\right.$ Sept. 2015). 